\title{
A Critique of Immanuel Wallenstein's World System Theory in The Modern World System.
}

\author{
Augustine EjioforOnyishi\&Chukwunonso Valentine Amoke.
}

\begin{abstract}
The Modern World System Capitalist Agriculture and The Origin of The European World Economy, is Immanuel Wallenstein's historical exposition of the structure and character of the prevailing global sociopolitical and economic relation. He made an insightful note on the exploitative nature of this relation. And the inevitable consequences are highlighted. The claims in this study are by no means original but by adding the semi-periphery in this analysis he has expanded the existing theory of global political economy from bimodal to trimodal structure. However, the strength of Wallenstein study lies not in the originality of its theory but on the fervent and pugnacious contention of the study that the contemporary global socio-political and economic composition would suffocate development in the periphery nations, undermine liberal democracy and promote global inequality. And ultimately favour the rich capitalist nation over the poor ones if the present trend is allowed to continue.
\end{abstract}

\section{INTRODUCTION}

Modern worlds system is a macro sociological perspective that seeks to explain the dynamics of the capitalist world economy, as a "total social system". In his Magnum opus, "Capitalist Agriculture and the origins of the European world-economy in the sixteenth century" (1974) Wallenstein made his most significant contribution to both sociology and globalization studies in the form of world system theory (Robinson, 2004), though unlike most Marxist historical studies that was concerned with analyzing the development of capitalist economy inequalities, world system theory does not concentrate on the relations between social classes or between the state and workers, but rather its focuses on the large borderless economic entity known as the world system. This unrelentless changing system is characterized by an unjust division of labour that produces unequal exchanging relations between different geographical areas of the globe. This entity called the world system is not maintained through consensual agreement or harmony of interest but rather through social forces that are in perpetual conflict, threatening to collapse the whole system (Galtung 1971, Amin 1976).

The modern world system followed the crises of the feudal system and helped explain the rise of Western Europe to world supremacy, between 1450 and 1670. Wallenstein's magnum opus provides analytical basis for a possible comprehensive understanding of the external and internal manifestation of the modernization process during this period and makes possible and analytical sound comparisons between different parts of the world (see below). Without ignoring the global historical contradictions that brought it to this stage.

\section{Section One}

i. The medieval epoch and prelude

Prior to sixteenth century, when Western Europe embarked on the part of capitalist development feudalism dominated western European society, between 1150-1300 both population as well as commerce expanded within the confines of the feudal system. However, from 1300-1450 this expansion ceased, creating a severe economic crises. According to Wallenstein (1974), the feudal crisis was probably caused by the interaction of these following factors.

1. Agricultural production fell or remains stagnant. This meant that the burden of peasants production increased as the ruling class expanded.

2. The economic cycle of the feudal economy has reached its optimal level; after which the economy began to shrink.

3. A shift of climatologically conditions decreases agricultural productivities within the population (1974: 21).

As a result to this domestic contradiction in the medieval economy it become no longer possible to increase productivity by investment of profits because of the inherent limitation of reward system of feudal social organization (1974:23). In other to counter stagnation, however, it became necessary to expand the system's land area and exploitable population base and to change the method of labour control. In the fifteenth century the European countries started their expansion into different part of the world, although this expansion was primarily directed to the Mediterranean and the Atlantic Islands, North and West Africa, Eastern Europe, 
Russia and central Asia. Therefore in the fifteenth century and early sixteenth century, the world economic system emerged. This was the first time that an economic system encompassed much of the world with link that superseded national or other political boundaries.

The expansion of European countries resulted in an increase of the land/labour ratio of the European dominated world economy. This made possible the large scale accumulation of basic capital which was used to finance the rationalization of agricultural production (1974:69).

\section{THE NEW EUROPEAN DIVISION LABOUR}

The new world economy differed from earlier empire system because it was not a single political unit. Empire depended upon a system of government which through commercial monopolies combined with the using of force directed the flow of economic goods from the periphery to the center. Empire maintained specific political boundaries within which they maintained control through an expensive bureaucracy and standing army. Only the technique of modern capitalists enabled the modern world economy unlike earlier attempts to extend beyond the political boundaries of any one empire (Wallenstein 1974). However, the long sixteenth century was characterized by similar inflation, the so called 'price revolution' which stimulated economic growth inflation led to forced savings and stimulated capital accumulation (1974:854).

In different part of the world economy different modes of labour control existed and were applied. Wage labour and self-employment dominated in the Western Europe. Slavery came to be used as a means of labour control in sugar production on the Atlantic Isands and later in the Caribbean and in America. In Hispanic America, coerced cash crops were also introduced as a means of labour control. According Wallenstein, the latter form of labour coercion differed from European feudalism. Though many scholars has seen or described it as a similar phenomenon" because the functions of the two mode of labour control were different (Hout 1993). Wallenstein stresses that European medieval feudal landlords produced for the domestic market, while American cash-crop production took place within the context of the capitalist world economy for the purpose of exportation (1974:91). The inclusion of external areas into the world economy enabled the core countries to specialized in more highly rewarded production, while the prophecy was transformed into monocultures.

In fact that new capitalist world system was based on an international division of labour that determined relationships between different regions as well as the types of labor conditions within each region (1974:99-120). In this model, the type of political system was also directly related to each region's placement within the world economy. As a basis of comparison, Wallenstein, proposes four different categories; (1) the core (2) the semi-periphery (3) the periphery and (4) the external, into which all regions of the world can be placed. The categories described each region's relative position within the world economy as well as certain internal political and economic characteristics.

\section{Section Two}

\section{The core or center states}

The core region of the world economy consist of the countries possessing relatively sophisticated production process, the core region benefited the most from the capitalist world economy. For the period under discussion, much of the northern Western Europe (England, France, and Holland) developed as the first core region. In this areas indigenous bourgeoisies have set up autonomous industries producing manufactured commodities for the world market. Politically the states within this region developed strong control government extensive bureaucracies and large machinery armies, this strong army helped the local bourgeoisies to obtain control over international commerce and extract capital supposes form this trade for their own benefit and the predominant modes of labour control have been wage labour and self-employment (1974:87). As the rural population expanded the small but increasingly of land less wage earners provided labour for farms and manufacturing activities.

The switch from feudal obligations to money rents in the aftermath of feudal crises encouraged the rise of independent or yeoman farmers but quizzed out many other peasants off the land. These impoverished peasants often moved to the cities, providing cheap labour essentially for the growth in urban manufacturing. Agricultural productivity increased with the proving of the commercial oriented independent farmer, the rise of pastorialism and improved farm technology. Historically the core of the modern world system has consisted of the countries in the northern Europe, North America (the United States and Canada) Japan, Australia and NewZealand can also be considered as core countries (1974:111).

\section{III.}

\section{THE PERIPHERY}

On the other end of the scale lay the peripheral zone. This zone has historically been dominated by relatively simple production processes, this means that countries in that part of the world learned to specialize in 
agriculture and raw materials production with badly rewarded labour, the export of the peripheral products has contributed in capital accumulation in the core because trade has been subject to unequal exchange (1984:82). Labour control has taken place by means of coercion, in the form of outright slavery or of feudalism (1974:87). The state structures of the peripheral countries are relatively weak, these areas lacked strong central government or were controlled by other states. Wallenstein described the optimal state structure of peripheral countries as one that (1) was not strong enough to interfered with the flow of commodities, capital and labour between this zones and the rest of the capitalist world economy (2) was strong enough to facilitate these flow (1984:80-2).

The core expropriated much of the capital surplus generated by the periphery through unequal exchange relations. Two areas Eastern Europe (especially Poland) and Latin America, exhibited characteristics of peripheral region, in Poland, Kings lost power to the nobility as region because a prime exporter of wheat to the rest of Europe. To gain sufficient cheap and easily controlled labour, land lords forced rural workers into a second serfdom" on their commercial estates. In Latin America, the Spanish and Portuguese conquest destroyed indigenous authority structures and replace them with weak bureaucracies under the control of these European states. Powerful local landlords of Hispanic origins became aristocratic capitalist farmers, enslavement of the native populations, the importation of African slaves and the coercive labour practices such as the "encomienda" and forced mine labour made possible the export of cheap raw materials to Europe (1974:90). Labour system in both peripheral areas differed from earlier forms in medieval Europe in that they were established to produce goods for a capitalist world economy and not merely for internal consumption. Furthermore, the aristocracy both in Eastern Europe and Latin America grew from third relationship with the world economy and could draw on the strength of a central core region to maintain control.

\section{IV.}

THE SEMI-PERIPHERY

Between the two extreme lie the semi-periphery, with respect to structural features such as the complexity of economic activities, the mode of labour control, the strength of the state machinery et cetera. These areas represented either core region in decline or peripheral region attempting to improve their relative position in the world economic system (1980:180). The semi-periphery is assigned as it were a specific economic role, but the reasons is less economic than political (1979:23). The political role of the semi periphery is that of a buffer between the two opposing forces (core and periphery) as such semi-periphery exhibited tension between the central government and a strong local landed class, good example of these declining core are Portugal and Spain; other semi-peripheries at this time were Italy, Southern Germany and southern France, economically these regions retain limited but declining access to international banking and the production of high-cost high quality manufactured good. Unlike the core, however, they failed to predominate in international trade and thus did not benefit to the same extent as the core. With weak capitalist rural economy landlords in semi-periphery resorted to share cropping (1974:103). This lessened the risk of crop failure for land powers, and made it possible at the same time to enjoy profit from the land as well as the prestige that went with landownership, according to Wallenstein the semi-periphery were both exploited and exploiter (1979:23) Spain for example imported silver and gold from its American colonies, obtained largely through coercive labour practices but most of this specie went into paying for manufactured goods from the core countries such as England and France rather than encouraging the formation of a domestic manufacturing sector. This however implies that the semi periphery partially deflects the political presumes which groups primarily located in the peripheral zone might otherwise direct against the core states and which operate within and through their state machineries (1974:350). One concept which deserved to be mentioned in the context of a discussion of Wallenstein's theory of the hierarchy of the capitalist world systems is "hegemony", though it is not the point in view here, we may come back to that latter.

V.

THE EXTERNAL AREAS

The capitalist world economy according to Wallenstein has expanded gradually over the last five centuries; it was not until the twentieth century that all the part of the world were incorporated into this world economy. Before the twentieth century large parts of the world still belong to the "external arena" of the world economy. Wallenstein argued that the defining characteristic of the external arena is the fact that production process can be accounted for by other considerations rather than the maximization of capital accumulation in the core (1989:130). These areas maintain their own economic system and for the most part managed to remain outside the modern world economy. Russia fits this case well, very well because unlike Poland Russia's wheat served primarily to supply its internal market. It traded with Asia as well as Europe; internal commerce remained more important than trade with outside regions. Also, the considerable power of the Russia state helped regulate the economy and limited foreign commercial influence, however, the incorporation of one of the parts of the external arena into the world economy has been described by Wallenstein in the following way: 
Incorporation means fundamentally that at least some significant production processed in a given geographic location become integral to several of the commodity chains that constitute the ongoing division of labour of the capitalist world economy (1989:130).

As Hopkins and Wallenstein (1981) have indicated there are at least four well-known features of incorporation into the periphery of the world economy. Integration of the previously external areas into the axial worldwide division of labour and interest system; specialization of production emphasizing produce and commodities that can be sold on the world market; the transformation of previously independent workers into "labour-in-relations-to capital".And the sacrament of the reproduction of capital.

\section{SECTION THREE}

\section{Stages of Growth}

The development of the modern world system or alternatively modern world economy lasted centuries, during which time difference region changed their relative position within the system.

Wallenstein divides the history of the capitalist world system into four states. Which was in this study simplified and divided into two basic phases?

\section{Stage 1 And 2}

This period followed the rise of the modern world system between 145-1670. When the Hapsburg Empire failed to convert the emerging world economy to a world empire, all the existing Western European states attempted to strengthen their respective position within the new world system. In order to accomplish this move, most of the states consolidated their internal political economic and social resources by;

a. Bureaucratization: This process aided the limited but growing power of the living. By increasing the state power to collect taxes, the kings eventually increase state power to borrow money and thereby further expand the state bureaucracy. At the end of this stage the monarch became the supreme power and instituted what has been called "absolute monarchy". Specifically during the crises of feudalism in the fifteenth century the nobility felt threatened by the peasant rebellions and turned to the kings for protection. The king exploited this situation by increasing taxation and strengthening the state apparatus or "bureaucracy. They developed strong standing armies purely monopolizing the use of physical force and legitimated their position by cultivating the ideology of absolutism, the divine right of kings (1974:133-47).

b. Homogenization of the local population, underline state involvement in the new capitalists systems and encourages the rise of indigenous capitalist groups, many core states expelled minorities. These independent capitalist groups without deep rooted local ties were perceived as threats to the development of strong core states. The Jews in England, Spain and France were expelled with the rise of resolute monarchy. Similarly, protestants, who were often the merchants in the catholic countries found they were targets of the catholic church. The catholic church, transnational institution found the development of capitalism and the strengthening of the state threatening (1974:152).

c. The expansion of the militia to support the centralized monarchy and to protect the new state from invasion.

$\mathrm{d}$. The concept of absolutism introduced at this period related to the relative independence of the monarch from previous established laws. This destination freed the kings from prior feudal laws.

e. Diversification of economic activities of the local bourgeoisie.

By 1640, Northwester European states secured their position as core states in the emerging economy. Spain and northern Italy declined to semi-peripheral status, while north Eastern Europe and Iberian American became peripheral zones. England gained ground steadily towards core status (1974:185). During this time, workers in Europe experienced a dramatic fall in wages; this wage fall characterized most European centers of capitalism with the exception of cities in the north and central Italy and Flounders. The reason for this exception of cities was that these cities were relatively older centers of trade, and the workers formed strong politicoeconomic group. The resistance of workers brought down the ability of employers to accumulate the large surplus necessary for the advancement of capitalism. Meanwhile employers in other part of Europe profited from the wage lag by accumulating large surplus for investment, they tried to increase their surplus either by expending the volume of export or by increasing the intensity of exploitation of the labourers (1980:129) in the Eastern European periphery, Corvéelabour was increased and competition was reduced by the buying out of producers. In the Hispanic America, the introduction of hacienda enables landowners to adjust production to changing demand on the world market (1980:136).

Long distance trade with the Americas and the east provided enormous profit for small merchant elite. Smaller merchant could not hope to enter this profiteering without the substantial capital and some state help. Eventually, the profits of the trans-Atlantic trade filtered down and strengthened the merchants hold over European agriculture and industries. Merchants with sufficient power accumulated profit through the purchase 
of goods prior to their production. By controlling the cost of finish products, merchants could extend their profit margin and control the internal market. This powerful merchant class provided the capital necessary for the industrialization of European core states.

\section{Stages 4 and $5\left(18^{\text {th }}\right.$ century and beyond)}

Industrial rather than agricultural capitalism represented this epoch, with shifting of emphasis on industrial production the following action and reaction characterized this era (a) European states participated in active explorations for exploitation of new markets (b) competitive world system such as the Indian Ocean system were absorbed into the expanding European world system with the independence of the Latin American countries, these area as well as previously isolated zones in the interior of the American continent entered as peripherals zones in the world economy. Asia and Africa entered the system in the nineteenth century as peripheral zone (c) The inclusion of African and Asia continents and peripherals zones increased the available surplus, allowing other areas such as the US and Germany to enhance their core status. (d) During this phase the core regions shifted from a combination of agricultural and industrial interest to purely industrial concerns. Between 1700, England's was Europe's leading industrial producers as well as the leader in agricultural production by 1900 only 10\% England population engaged in agriculture. (e) By the 1900s with the shift toward manufacturing, core areas encourages the rise of industries in the peripheral zones so that they could sell machines to these region with excess profit.

\section{THEORETICAL REPRISE}

The capitalist world economy, as envision by Wallenstein, is a dynamic system which change over time. However, certain basic features remain in place. Perhaps most important is when one examines the dynamics of this system the core region of northern western Europe clearly benefited the most from this arrangement. Though extremely high profit from international trade and from an exchange of manufactured goods for raw material form the peripherals zones and to a loser extent from the semi-periphery. The core enriches itself at the experience of the both semi-periphery and peripheral economies. This of course did not mean either that everybody in the periphery become poorer or that all citizens of the core regions become wealthier as a result. In the periphery, landlords for example often gain great wealth at the expense of their under paid coerced labourers, since landowners were able to expropriate most of the surplus of their workers for themselves. In turn, in the core regions many of the rural inhabitants increasingly landless and forced to word as wage labourers, at least initially saw a relative decline in their standard of living and in the security of their income. Overall, certainly Wallenstein sees the development of the capitalist world economy as detrimental to a large proportion of the world's population.

Through this theory, Wallenstein attempt to explain why modernization had such wide ranging different effects on the world. He shows how political and economic conditions after the breakdown of feudalism transformed Northwestern Europe into the predominant commercial and power.

The geographic expansion of the capitalist world economy altered political system and labour condition where ever its able to penetrate. Though the functioning of the world economics appears to create increasingly larger disparities between the various types of economies, the relationship between the core and its periphery and semi-periphery remain relative, not constant. Technological advantages, for example could lead to an expansion of the world economy as a whole and precipitate change in some peripheral or semi-peripheral areas.

Finally, Wallenstein contends that an explicit analysis of the history of capitalist world system show that it has brought about a vertical development in which economic and socio-political disparities between sections of the world economy have increased rather than provide prosperity globally.

\section{BIBLIOGRAPHY}

[1] Amin, S, (1977).Imperialism and unequal development. Hassocks, Harvest press.

[2] Goldfrank, W. (2000). "Paradigm regained" the rule of Wallenstein's world-system method", Journal of world system research, vol. 6 No. 2.

[3] Hopkins, T. K and Wallenstein (1981). "Structural transformation of the world economy" In R. Robinson (eds) Dynamics of world development, New York, Columbia University Press.

[4] Robinson, W (2004), A theory of Global Capitalism: Class andState in a Transnational World. Baltimore, MD Johns Hopkins.University Press.

[5] Robinson, W. (2004)."From State Hegemony to transnational Hegemony: A global capitalism approach". In IReifer (ed) Globalization, Hegemony and Power: Antisystemic Movement and global system, Boulder, Co: Paradigm Press. 
[6] Wallenstein, I (1984).The politics of the world economy: The state, the movement and the civilization, Cambridge, Cambridge University press.

[7] Wallenstein, I. (1974).The modern world system: Capitalist agriculture and the origin of the European world-economy in the sixteenth century, New York, Academic press.

[8] Wallenstein, I. (1980) .'Imperialism and development", in A Bergeson (ed) Study of the modern world system, New York, Academic Press.

[9] Wallenstein, I. (1982). "World system analysis: Theoretical and interpretative issues" in T. K. Hopkins, I Wallenstein, R. L. Bach, C. Chase-Dunn and R. Mukherjee (ed) World system analysis: Theory and methodology Exploration in the world economy, Beverly Hill, Sage publishers.

[10] Wallenstein, I. (1984)."Household structure and the labour force. Formation in the capitalist world economy", In J. Smith, I Wallenstein and H. D. Evers (eds) Household and the world economy, Explorations in the world economy, Beverly Hills, Sage publishers.

[11] Wallenstein, I. (2000).The Essential Wallenstein, New York, The New York press. 